\title{
Xanthogranulomatous pyelonephritis
}

\author{
Tahmina Begum, Muhammad Ekramul Huq, Mashrafi Ahmed
}

Texas Tech University, Amarillo, Texas, USA

\section{Correspondence to} Dr Mashrafi Ahmed, mashrafiahmed@gmail.com

Accepted 2 June 2016

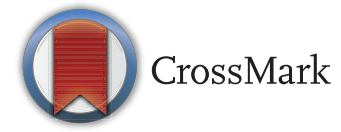

To cite: Begum T, Huq ME, Ahmed M. BMJ Case Rep Published online: [please include Day Month Year] doi:10.1136/bcr-2016216025

\section{DESCRIPTION}

A 48-year-old African-American woman was admitted to the hospital, because of weight loss and poor appetite for the past 3 months. The patient mentioned that she had nearly $30 \mathrm{lb}$ of unintentional weight loss during this period. She had neither nausea, vomiting nor chest pain, but had felt mildly feverish with left-sided back and flank pain for the past 2 weeks. The pain was $5 / 10$ in intensity. There was no change in urine frequency, and neither colour change in the urine nor burning on micturition. There was no blood in the urine. The patient mentioned occasional night sweats for the past 2 weeks as well. On two occasions, respectively, she measured her temperature to be $102^{\circ} \mathrm{F}$ and $101.6^{\circ}$ F. At the time of admission, her temperature was $99.6^{\circ} \mathrm{F}$ and heart rate $120 \mathrm{bpm}$. Physical examination revealed left-sided costovertebral angle tenderness with an ill-defined mass extending up to the costal margin. Initial white cell count was $22.6 \times 10^{3} / \mu \mathrm{L}$ with $85 \%$ neutrophils, and urinalysis was indicative of urine infection. A CT scan of the abdomen and pelvis with intravenous contrast revealed a markedly enlarged left kidney with diminished perfusion. There were multiple lowdensity areas throughout the kidney, suggestive of necrosis or abscess (figures 1 and 2; yellow arrow). There was a little stag horn calculus at the renal pelvis (figure 2; green arrow). There was also perinephric fat stranding with retroperitoneal lymphadenopathy. The diagnosis of xanthogranulomatous pyelonephritis was suggested. A renal biopsy was performed to rule out malignancy, which further confirmed chronic granulomatous inflammatory changes in the renal parenchyma. The patient was started on an intravenous antibiotic with ceftriaxone for initial management. Eventually, she underwent left-sided total nephrectomy.

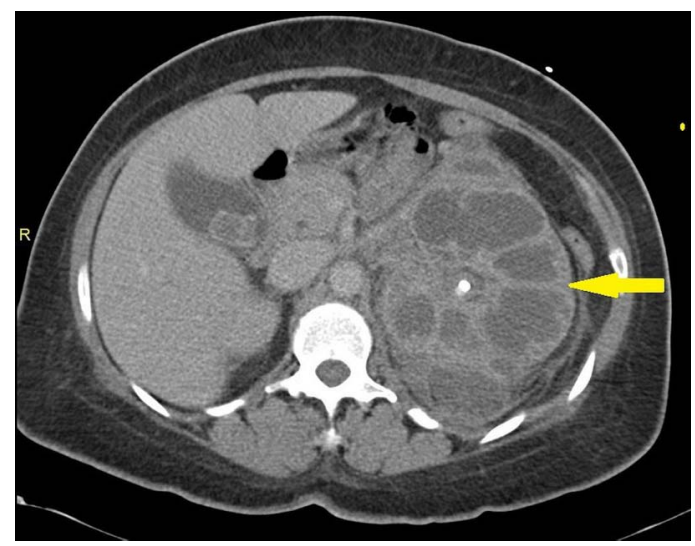

Figure 1 (A) CT scan of the abdomen and pelvis showing a large left kidney with multiple areas of low density suggestive of necrosis or abscess (yellow arrow).

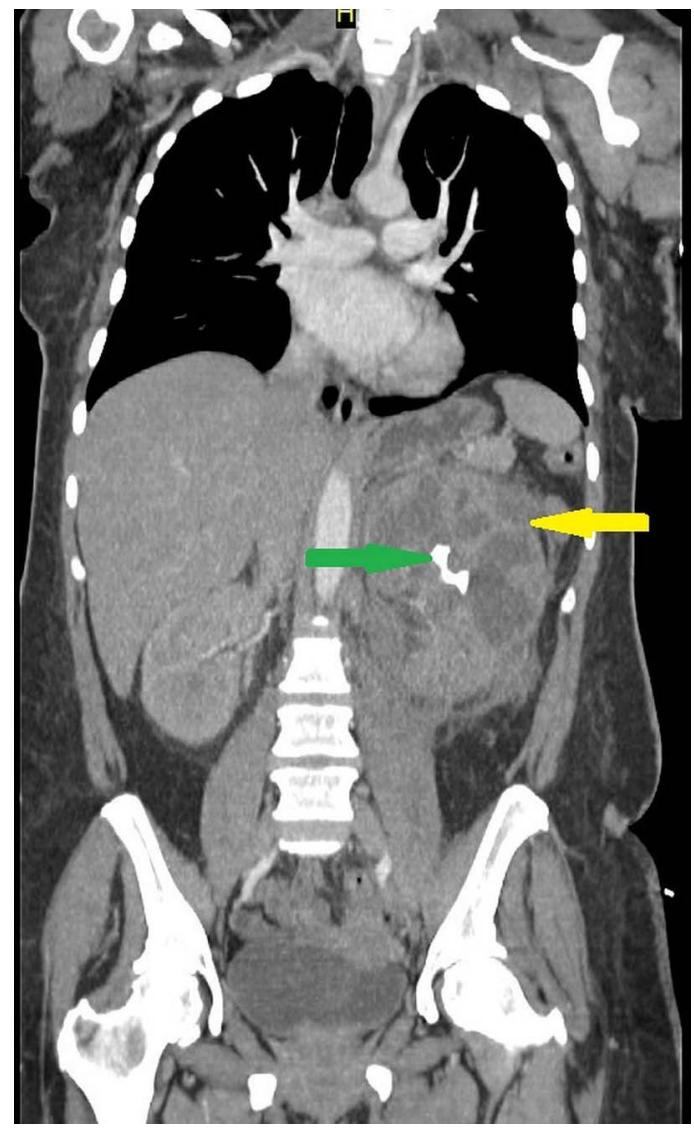

Figure 2 (A) CT scan of the abdomen and pelvis showing xanthogranulomatous pyelonephritis (yellow arrow) and stag horn calculus at the renal pelvis (green arrow).

\section{Learning points}

Xanthogranulomatous pyelonephritis is a granulomatous inflammation of the renal parenchyma due to chronic urinary tract infection often associated with renal stones.

- On the ultrasound and CT scan image, it is detected as an enlargement of the kidney, with multiple hypoechoic areas, calyceal dilation, necrosis, abscess and, often, inflammation extending to the perinephric fat and retroperitoneum.

- Fine-needle aspiration biopsy is recommended to confirm the diagnosis.

- Since it is an irreversible condition, total nephrectomy is recommended.

Xanthogranulomatous pyelonephritis is the chronic inflammation of the renal parenchyma, and is rarely encountered in clinical medicine. It 
is characterised by tubulointerstitial damage with chronic interstitial inflammation and lymphoid follicle formation. It also consists of solid sheets of lipid filled foamy macrophages, inflammatory cells and extensive fibrosis. ${ }^{1}$ Multiple discrete abscesses are common. Xanthogranulomatous pyelonephritis is mostly diffuse (92\%) and occupationally focal (8\%). ${ }^{1}$ It usually develops during prolonged kidney infection by obstructive uropathy due to renal stones. The commonly isolated organisms are Proteus spp. and Escherichia coli. ${ }^{2}$ Ultrasound and CT scan are both sensitive diagnostic tools. Review of image findings of 21 cases by $\mathrm{Kim}^{3}$ reported presence of renal calculi in $76 \%$ and hydronephrosis in $81 \%$ of cases. Since the image findings may also mimic Wilms tumour, neuroblastoma, clear cell carcinoma, malacoplakia, pyonephrosis or minimal tuberculosis, tissue biopsy to confirm the diagnosis is recommended. Although partial nephrectomy can be performed for focal disease, most cases require total nephrectomy for resolution of symptoms.

Competing interests None declared.

Patient consent Obtained.

Provenance and peer review Not commissioned; externally peer reviewed.

\section{REFERENCES}

1 Samuel M, Duffy P, Capps S, et al. Xanthogranulomatous pyelonephritis in childhood. J Pediatr Surg 2001;36:598-601.

2 Yiğiter M, Ilgici D, Celik M, et al. Renal parenchymal malacoplakia: a different stage of xanthogranulomatous pyelonephritis? J Pediatr Surg 2007;42:E35-8.

$3 \mathrm{Kim} \mathrm{JC.} \mathrm{US} \mathrm{and} \mathrm{CT} \mathrm{findings} \mathrm{of} \mathrm{xanthogranulomatous} \mathrm{pyelonephritis.} \mathrm{Clin} \mathrm{Imaging}$ 2001;25:118-21.

Copyright 2016 BMJ Publishing Group. All rights reserved. For permission to reuse any of this content visit http://group.bmj.com/group/rights-licensing/permissions.

BMJ Case Report Fellows may re-use this article for personal use and teaching without any further permission.

Become a Fellow of BMJ Case Reports today and you can:

- Submit as many cases as you like

- Enjoy fast sympathetic peer review and rapid publication of accepted articles

- Access all the published articles

- Re-use any of the published material for personal use and teaching without further permission

For information on Institutional Fellowships contact consortiasales@bmjgroup.com

Visit casereports.bmj.com for more articles like this and to become a Fellow 